Stevphen Shukaitis. Imaginal Machines: Compositions of Autonomy \& Self-Organization in the Revolutions of Everyday Life. Brooklyn, NY: Autonomedia, 2009. Pp. 256. $\$ 16.00$ (paper).

\title{
ISBN 978-1570272080
}

\section{Reviewer: Benjamin Shepard ${ }^{1}$}

[Article copies available for a fee from The Transformative Studies Institute. E-mail address: journal@transformativestudies.org Website: http://www.transformativestudies.org (C2010 by The Transformative Studies Institute. All rights reserved.]

So what ever came of the calls for "power to the imagination" from the streets of Paris? In a world in which resistance movements are often commodified, neutralized or absorbed by an increasingly resilient system, where do we go with these sentiments? Where do we take them? If we are to take such surreal ambitions seriously, we'd best drive imaginal machines, beckons anti-authoritarian thinker Stevphen Shukaitis, even if they tend to crash and break down. Yet, this fact is probably most appropriate, explains the author. For Shukaitis, "imaginal machines" are "composed by the affective states they animate, reflecting the capacities to affect and be affected by the worlds that are contained within them. They activate a cartography of thought." Such mechanics propel us through our political wanderlust. "Themes of imagination, creativity and desire run throughout the radical left movements, and the so-called 'other workers' movement," explains Shukaitis. While such thinking ties together projects from Kurt Sphitters to Andrew Breton to today's Critical Mass bike rides, it does not appear on a large scale until the 1960's. Still, the author suggests, "they exist within a secret drift of history that runs from medieval heresies to bohemian dreams of the Big Rock Candy Mountain in the 1930s. It is a drift that connects Surrealism with migrant workers, the IWW with Dadaism, and back again." While these impulses are often neglected or obfuscated by positivist currents and debates about the merit of political opportunity structures, "they find channels of influence in collective dreams and a pervasive yearning for freedom." (p.14).

In order to contend with these daydreams, Shukaitis turns to the concepts of everyday life and autonomy. Why everyday life? the author

\footnotetext{
${ }^{1}$ Benjamin Shepard, PhD, is the author of Queer Politics and Political Performance. Address correspondence to: Benjamin Shepard; e-mail: benshepard@mindspring.com.
}

1937-0229 C2010 Transformative Studies Institute 